\title{
The Assessment of Micronutrients Loss in Pasteurized Meat Products with Added Vegetable Oils
}

\author{
Tamara Elena Mihociu ${ }^{1 *}$, Florentina Roming Israel ${ }^{2}$, Nastasia Belc ${ }^{1}$ and Elisabeta Botez ${ }^{3}$ \\ ${ }^{1}$ National R\&D Institute for Food Bioresouces-IBA, Dinu Vintila Street, No. 6, 021102, Bucharest, Romania \\ 2University for Agronomical Sciences and Veterinary Medicine Bucharest/CBAB Biotehnol, B-dul. Marasti Street, No. 59, Bucharest, Romania
}

${ }^{3}$ Food Science and Engineering Faculty, Dunărea de Jos University, Domneasca Street, No. 111, Galati, Romania

\begin{abstract}
Lipids are essential nutrients for human health. The nutritional value of the lipids and the recommended daily consumption has been evaluated by the FAO experts in order to establish indicators for lipid quality, such as: polyunsaturated fatty acids/ saturated fatty acids report is 1 and $n 6 / n 3$ report is 3 . This study has assessed the fatty acids content of the lipids in a meat product (boiled-smoked salami) with addition of sea bucthorn vegetable oil (Hippophaë rhamnoides L.) and walnut oil (Juglans Regia L). The vegetable oils have been added in order to reduce the saturated fatty acids content and to increase the polyunsaturated and mono-unsaturated fatty acids content, tocopherols and carotenoids. The evolution of the chemical caracteristics of the salami samples was monitorized by NIR spectofotometery (FoodScan); vitamin E content by RP-HPLC; the antioxidant capacity of vitamins from oils through chemiluminiscenta (Photochem); lipid profile by gaschromatography of fatty acids from the lipid fractions of the samples for a period of 18 days of storage, at refrigeration temperatures. The lipid profile ( $\mathrm{g}$ fatty acids $/ 100 \mathrm{~g}$ fatty acids), the vitamin $E$ content ( $\mathrm{mg} / 100 \mathrm{~g}$ fatty acids), the antioxidant capacity ( $\mu \mathrm{molTE} / \mathrm{g}$ fat) can offer informations about nutritive value of the salami dish with vegetable oils added and the evolution of the lipids in the oxidation process.
\end{abstract}

Keywords: Meat products; Lipid profile; Nutritional value; Vegetable oils

\section{Introduction}

The epidemiological studies have lighted the connection between the total consumption of lipids, the nutritional profile of lipids and human health, demonstrating the assigning of the important fatty acids groups with effects against the health. The medical research showed the role of essential fatty acids in reduction of cardiovascular diseases, diabetes, the nervous system, immunity, reducing Low-Density Lipoprotein Cholesterol (LDL) and increase High-Density Lipoprotein Cholesterol (HDL) [1]. Depending on catena length, fatty acids have different effects in the metabolism and human health. For example, lauric acid (C12:0), miristic acid (C14:0) and palmitic acid (C16:0) increase LDL cholesterol while stearic acid (C18:0) doesnt have any effect.

There are evidences as:

- $\quad$ Replacement of saturated fatty acids (SFAs) (C12:0-C16:0) with polyunsaturated fatty acids (PUFAs) can decrease the LDL cholesterol concentration and the report of total cholesterol/HDL cholesterol also.

- $\quad$ Replacement of SFAs (C12:0-C16:0) with monounsaturated fatty acids (MUFAs) can reduce the concentration of LDL cholesterol and the total cholesterol/HDL cholesterol report, in a smaller percent than PUFAs. Replacement of carbohydrates with MUFAs can increase the HDL cholesterol concentrates [1,2].

The lipid profile of the meat products is, on average, of: $41 \%$ SFAs $/ 42 \%$ MUFAs $/ 15 \%$ PUFAs. The meat products from the category of boiled-smoked salami have a composition with a high fat content (25-45\%), originating in the meat and the back fat that is added in the recipe. The back fat has an important role in the meat products by improving the texture, the taste and flavour, as well as an important economic role. The quality of fat for red meat it is influenced by the genetic material, the quality of fodder, the growing system, the anatomical pieces used for processing. The oleic acid prevail in muscles and in the adipose tissue of the pigs, sheeps and cows, while the palmitic acid is the main fatty acid in these tissues. There are very low quantities of Eicosapentaenoic Acid (EPA) and Docosahexaenoic Acid (DHA) in the red meat. PUFAs with long catena $n-6$ and $n-3$ are found in the cow muscles and in the adipose tissue in the form of fosfolipids (variable quantity, influenced by the facts mentioned previously).

Concerns for reducing fat content in the meat products resulted in the elaboration of different techological models: to replace the back fat with proteins from other sources and water, by adding polyglucids with a mimethic role [3]. Increasing of the nutritional value of the lipids in the meat products was achieved through:

- $\quad$ Feeding conducted of animals in farms by obtaining carcass with high content of EPA and DHA [4-6].

- $\quad$ By adding of ingredints rich in PUFAs in meat products as: algae [7], oil seeds, rich oils in fatty acids $\omega 3$ [8-11].

This study was aimed at evaluating the influence, antioxidant capacity and fatty acid profile of the fat soluble vitamins when adding vegetal oils at boiled and smoked salami formulation [12]. We have used walnut (Juglans Regia L.) $[11,13,14]$ and sea-buckthorn (Hippophaë rhamnoides L.) oils, rich in linoleic and a-linolenic fatty acids as well as in tocopherols and carotenoids [15-17]. It is well known that polyunsaturated fatty acids are unstable in the presence of oxygen, light and high temperature [18]. The oxidative processes are accelerated

*Corresonding author: Tamara Elena Mihociu, National R\&D Institute for Food Bioresouces-IBA, Dinu Vintila Street, No. 6, 021102, Bucharest, Romania, Tel: +40316205833; E-mail: tamaramihociu@yahoo.com

Received August 01, 2014; Accepted December 06, 2014; Published January 07, 2015

Citation: Mihociu TE, Israel FR, Belc N, Botez E (2015) The Assessment of Micronutrients Loss in Pasteurized Meat Products with Added Vegetable Oils. J Food Process Technol 6: 411. doi:10.4172/2157-7110.1000411

Copyright: (c) 2015 Mihociu TE, et al. This is an open-access article distributed under the terms of the Creative Commons Attribution License, which permits unrestricted use, distribution, and reproduction in any medium, provided the original author and source are credited. 
when processing meat $[19,20]$ due to an increase in the surface exposure during mincing, mixing and due to the high pasteurization temperature that leads to the protein denaturisation and an increase in the availability of the heme iron which can accelerate the oxidative interactions. The study has evaluated the synergic antioxidant effect of the fat soluble vitamins from the samples formulated with vegetal oils against the samples formulated with solid fat. The synergic antioxidant capacity of carotenoids, tocopherols, sodium nitrite and sodium polyphosphates was performed by chemical analysis (humidity, total protein, total fat content, $\mathrm{pH}$ ). Tocopherol and fatty acid content has been assessed during storage in correlation with the evolution of the Peroxide Value (PV) and the total Antioxidant Capacity (AC).

\section{Experimental Section and Methods}

\section{Salami manufacturing}

The smoked and boiled salami samples were formulated with pork and beef meat, fat (for the control), carrageenan, walnut oil and seabuckthorn oil, in three versions: P1-sample with back fat; P2-sample with walnut oil; P3-sample with sea buckthorn oil. At the formulation of the salami samples no condiments, colorants, taste potentiating substances, flavors, ascorbic acid or its salts were used, so that it will not interfere with the antioxidant capacity assessment.

The salami samples were manufactured from a mixture of meat batter (where the oil has been incorporated) and meat grind (brine mixed with minced meat), grind in which the meat pieces had an approximate dimension of 5-13 $\mathrm{mm}$. The meat batter was manufactured with the help of the bowl mixer cutter using pork and beef leg (59/41), carrageenan $(3.65 \%)$, salt $(1.6 \%)$, sodium polyphosphates $(0.3 \%)$ and sodium nitrate $(10 \mathrm{mg} / \mathrm{Kg})$. Sample recipe was as follows: pork $53.7 \%$, beef $20.8 \%$, carrageenan $1.0 \%$, salt $1,6 \%$. The fat added to sample was represented by hard fat $4,14 \%$ in control P1, walnut oil $4,14 \%$ in P2 and sea-buckthorn oil 4, 14\% in P3.

The filling was performed with a vacuum filling machine, into 90 $\mathrm{mm}$ diameter permeable casings.

The thermal process was performed during several steps: drying, hot smoking $45^{\circ} \mathrm{C}$, boiling $70^{\circ} \mathrm{C}$, drying, smoking. Storage was performed at $2-4^{\circ} \mathrm{C}$, for 18 days.

\section{Determinations methods}

Chemical composition: Moisture, \%, total protein, \%, collagen, $\%$, using NIR spectrophotometer (Food Scanner) for meat, type 78810, with ANN calibration, FOSS Analytical. The accuracy interval was $0.4-$ $0.8 \%$ for moisture and $0.3-0.6 \%$ for total protein. The $(300 \mathrm{~g})$ salami sample is minced so that it can pass through a $5 \mathrm{~mm}$ sieve, distributed evenly onto the equipment tray. The sample is scanned and the results are processed by the equipment's software and displayed as percentage.

Total fat, \%, was performed by Soxhlet method, the extraction was performed with petroleum ether according to SR ISO 1443/2008.

The lipid profile: Fatty acids, g/100 g fatty acids, measured by a gaschromatographic method according to SR CEN ISO/TS 17764-2: 2008, SR CEN ISO/TS 17764-1:2008.

Content in vitamin E: Sample preparation consisted in saponification using $11 \%$ ethanol solution of $\mathrm{KOH}$ and ascorbic acid for preventing vitamin $\mathrm{E}$ oxidation, at $80^{\circ} \mathrm{C}$, for 15 minutes. After cooling, $4 \mathrm{ml}$ iso-octane was added in each sample, followed by vortexing for 2 minutes. $1 \mathrm{ml}$ Iso-octane extract was evaporated using a centrifugal evaporator and fatty residue was reconstituted in $0.5 \mathrm{ml}$ methanol. All the samples were prepared and analyzed in triplicates.

Separation of tocopherols was carried out by RP-HPLC using a Waters Alliance system with UV detector. The data were achieved and processed with EMPOWER 2.0 specialized software. The column was a C8 Symmetry $(150 \times 3.9 \mathrm{~mm}, 5.0 \mu \mathrm{m}$ particle size $)$. The mobile phase consisted in methanol+acetonitrile+water solution $(45: 45: 10, \mathrm{v} / \mathrm{v} / \mathrm{v})$ and the elution was performed at a flow rate of $1 \mathrm{ml} / \mathrm{min}$.

Calibration curve was obtained using $67.35 \mu \mathrm{g} / \mathrm{ml}$ a-tocopherol (Sigma-Aldrich) standard solution and the results were calculated and expressed as $\mathrm{mg} \alpha$-tocopherol in $100 \mathrm{~g}$ fat.

Assessment antioxidant capacity: Peroxide value (PV), in meq/ $\mathrm{kg}$, according to AOAC 965.33/2006 method;

The Antioxidant Capacity (AC), in $\mu \mathrm{mol} \mathrm{TE} / \mathrm{g}$ fat, measured using the protocol for the determination of the Lipid Soluble Compounds (ACL) with PHOTOCHEM equipment, Analytik Jena. The method implies lipid extraction from a $70 \mathrm{~g}$ sample by stirring (for 10 minutes) with $100 \mathrm{ml}$ chloroform in the presence of $(40 \mathrm{~g}) \mathrm{Na}_{2} \mathrm{SO}_{4}$ anh., (adapted AOAC 965.33 method), UV exposure of $10 \mu \mathrm{l}$ from the filtered for the optic excitation in the presence of a photosensitizing substance to release radicals of the superoxide ion $\mathrm{O}_{2}$. Residual free radical assessment (after the interaction with antioxidants) is done with the photosensitizing substance (Luminol). The measurement parameter ACL: $I_{D} / I_{B}=$ inhibition, is achieved by solving the integral under the curve (control and sample): $I_{D}=I_{B}-I_{P}$ The establishment of the calibration curve was done with 6-hydroxy-2,5,7,8tetrametilchroman-2-carboxylic acid. AC is expressed as $\mu \mathrm{mol} / \mathrm{nmol}$ Trolox. Reproducibility CV 2-5\% Trolox. The results are displayed in units called Trolox Equivalent: e.g. $\mu \mathrm{mol} \mathrm{TE} / 1 \mathrm{~g}$ fat.

\section{Calculation:}

$\mathrm{AC}=(\mathrm{AC} / \mathrm{m}) \times \mathrm{D}(\mu \mathrm{mol} \mathrm{TE} / 1 \mathrm{~g}$ fat $)$

where:

$\mathrm{AC}=$ antioxidant capacity, $\mu \mathrm{mol} / \mathrm{nmol} \mathrm{TE} / \mathrm{g}$ fat;

$\mathrm{m}=$ amount of fat from $10 \mathrm{ml}$ the chloroform extract;

$\mathrm{D}=$ dilution of the chloroform extract.

The chemical measurements were performed for raw materials and the salami samples, at refrigeration temperatures $\left(2-4^{\circ} \mathrm{C}\right)$, during storage. The sampling was done at 7 days intervals, estimating that this would be enough time for lipid oxidation reactions to take place.

\section{Results}

\section{Chemical composition}

Chemical composition raw materials: From the chemical analysis of the raw materials the following pork leg muscles were selected:biceps femoris and semimembranosus that have a chemical composition suitable for meat paste with added oil due to the collagen content, which is $62 \%$ lower than the one found in the quadriceps group-Vastus (Table 1) and according to the literature, a content of iron lower with $30 \%$ (7.6-8.7 mg/100 g versus $10-14 \mathrm{mg} / 100 \mathrm{~g}$ of quadriceps groupVastus) represents slow, less vascularized muscles (Table 2).

Chemical composition salami samples: The chemical composition of the salami samples macronutrients are within acceptable limits, the products belonging to the same semi-finished products:

- $\quad$ moisture, \%, P2-0.89\%; P3-1.00\%; to the value P1; 


\begin{tabular}{|l|l|c|c|c|c|}
\hline \multirow{2}{*}{$\begin{array}{l}\text { Chemical } \\
\text { characteristics }\end{array}$} & unit & \multicolumn{4}{|c|}{ Results* } \\
\cline { 3 - 6 } & & $\begin{array}{l}\text { Biceps femoris and } \\
\text { semimembranosus }\end{array}$ & $\begin{array}{c}\text { Quadriceps } \\
\text { group-Vastus }\end{array}$ & Beef leg & Back fat \\
\hline Moisture & $\%$ & 73.3 & 74.5 & 74.9 & 18.72 \\
\hline $\begin{array}{l}\text { Total protein } \\
\text { din care } \\
\text { collagen }\end{array}$ & $\%$ & 19.9 & 19.84 & 20.87 & 3.21 \\
\hline Total lipids & $\%$ & 0.15 & 0.4 & 0.08 & 0.85 \\
\hline
\end{tabular}

${ }^{*}$ Media a trei determinari este $<0.5 \%$

Table 1: Chemical composition of meat and back fat

\begin{tabular}{|l|c|c|c|c|}
\hline \multirow{2}{*}{ Samples with } & \multicolumn{4}{|c|}{ Results* } \\
\cline { 2 - 5 } & $\mathbf{p H}$ & Moisture, \% & Total protein, \% & Total crude fat, \% \\
\hline P1-back fat & 6.27 & 66.19 & 19.32 & 13.45 \\
\hline P2-walnut oil & 6.15 & 65.30 & 19.21 & 11.52 \\
\hline P3-sea buckthorn oil & 6.35 & 65.96 & 18.87 & 12.18 \\
\hline
\end{tabular}

${ }^{*}$ The values shown in the table represent the average of three determinations with $\mathrm{RSD}<5 \%$

Table 2: Chemical composition salami samples.

\begin{tabular}{|l|c|c|c|c|}
\hline $\begin{array}{l}\text { Fatty acids (g/100 g } \\
\text { fatty acids) }\end{array}$ & Back fat & Pig leg* & Walnut Oil & Sea buckthorn oil \\
\hline C12:0 & 0.177 & 0.290 & 0.00 & 0.00 \\
\hline C14:0 & 2.143 & 2.030 & 0.04 & 0.11 \\
\hline C16:0 & 25.930 & 22.743 & 7.75 & 12.25 \\
\hline C16:1 & 3.303 & 1.930 & 0.17 & 3.19 \\
\hline C17:0 & 0.210 & 0.373 & - & - \\
\hline C17:1 & - & - & - & - \\
\hline C18:0 & 12.663 & 12.373 & 2.22 & 2.25 \\
\hline C18:1n9 & 38.637 & 36.840 & 16.33 & 54.06 \\
\hline C18:2n6 & 13.700 & 19.723 & 62.45 & 26.90 \\
\hline C18:3n3 & 1.027 & 1.050 & 10.90 & 0.70 \\
\hline C20:2n6 & 0.317 & 0.687 & 0.00 & 0.23 \\
\hline C20:3n6 & - & - & 0.14 & 0.17 \\
\hline C20:4n6 & 0.007 & 0.264 & - & - \\
\hline$\sum$ SFAs & 41.438 & 38.393 & 10.01 & 14.61 \\
\hline$\sum$ MUFAs & 42.044 & 38.839 & 16.50 & 57.25 \\
\hline S PUFAs & 15.697 & 22.09 & 73.49 & 28.0 \\
\hline PUFAs/SFAs & 0.379 & 0.575 & 7.34 & 1.916 \\
\hline
\end{tabular}

The values shown in the table represent the average of 3 determinations with $\mathrm{RSD}<5 \%$ *Pig leg reprezinta semimembranosus and biceps femoris muscle.

Table 3: Fatty acids compozition, \% fatty acids, fat and oil raw materials.

- $\quad$ total protein, \%, P2-0.11\%; P3-0.45\%; to the value P1;

- $\quad$ total crude fat, \%, P2-1.93\%; P3-1.27\%; to the value P1.

The difference in the amount of crude fat between the salami samples is due to the adherent fat of the biceps femoris muscle, out of which the meat grind was made and due to the coarse structure of the meat paste. It was found that the macronutrient balance is not affected by the replacement of lard with vegetable oil.

\section{Lipid profile}

Lipid profile raw materials and oils: The lipid profile determined for the raw materials and ingredients used in the experiment are within the values found in publications for pig carcasses obtained through intensive technologies [21] and chemical composition of the oil [15,22] (Table 3).

Note that for both the content of palmitic acid and oleic acid, the values obtained in the meat are comparable to those found in the literature, which are within the following range: $23.20-27.29 \mathrm{~g} \%$ for palmitic acid, $39.67-47.00 \mathrm{~g} \%$ for oleic acid, respectively [20]. The lard sample registered a content of $41.43 \%$ of saturated fatty acids, among which the palmitic acid was predominant $(25.93 \%)$. A large percentage of PUFAs are found in walnut oil $73.49 \mathrm{~g} / 100 \mathrm{~g}$ fatty acids, compared to the literature $(69.55 \pm 0.03-75.54 \pm 0.51)$ [15]. A large percentage of MUFAs was found in the seabuckthorn oil, $57.25 \mathrm{~g} / 100 \mathrm{~g}$ fatty acids, higher than the values found in the literature (52.823-54.32\%) [22]. Regarding the oils, the palmitic acid is $36.7 \%$ higher in seabuckthorn oil compared to the walnut oil and approximately $50 \%$ lower than in meat and lard. The main MUFA acid, the oleic acid, has the highest value in the seabuckthorn oil ( $70 \%$ compared to the walnut oil and $28 \%$ compared to the average value of meat and fat). The linoleic acid has the highest value in walnut oil $(73 \%$ higher than the average value of meat and fat and $56.92 \%$ higher than in seabuckthorn oil). Regarding the $\alpha$ linolenic acid, this is present in appreciable amounts in walnut oil and in the smallest amount in seabuckthorn oil.

Lipid profile salami samples: The lipid profile of the fat found in salami samples (Table 4) reflects the source of fat of each sample. P1with back fat has the highest content of SFAs; P2-with walnut oil has a high content of PUFAs; P3-with seabuckthorn oil has a high content of MUFAs. The ratio PUFAs/SFAs is close to optimal for the sample $\mathrm{P} 3=0.95$. $\mathrm{P} 2$ has a ratio three times higher than the recommended one (PUFAs/SFAs=1.1), while P1-the blank has a ratio of $40 \%$ less.

Quantity of fatty acids reported to $100 \mathrm{~g}$ salami (Label 5) in samples with added oil covers the total fat recommended of daily consumption for adults [3]:

$\begin{array}{ll}\text { - } & \text { SFAs } \\ \text { - } & \text { MUFAs } \\ \text { - } & \text { LAFAs } \\ \text { - } & \text { ALA: }\end{array}$

$$
\begin{aligned}
& \mathrm{P} 2=15,6 \% ; \\
& \text { P2=18.47\%; } \\
& \text { P2=45.28\%; } \\
& \text { P2=47.08\%; } \\
& \text { P2 }=22.3 \% ;
\end{aligned}
$$$$
\text { P3=23.46\%; }
$$

P3=38.33\%;

P3 $=20.42 \%$

$\mathrm{P} 3=23.01 \%$;

$\mathrm{P} 3=2.57 \%$.

A report PUFAs/SFAs (optimum=1.1) was recorded at $\mathrm{P} 3=0.957$.

The evolution of quantity of fatty acid/100 $\mathrm{g}$ fatty acids in salami samples during storage

\begin{tabular}{|l|c|c|c|}
\hline \multirow{2}{*}{$\begin{array}{l}\text { Fatty acids } \\
\text { (g/100 g fatty acids) }\end{array}$} & \multicolumn{3}{|c|}{ Samples with* } \\
\hline C14:0 & Back fat & Walnut oil & Sea buckthorn oil \\
\hline C15:1 & 0.22 & 0.56 & 1.0 \\
\hline C16:0 & 22.35 & 0.17 & 0.18 \\
\hline C16:1 & 3.68 & 12.36 & 17.63 \\
\hline C17:0 & 0.32 & 0.13 & 3.39 \\
\hline C17:1 & 0.32 & 0.15 & 0.19 \\
\hline C18:0 & 9.15 & 4.36 & 0.19 \\
\hline cis C18:1n9 & 42.44 & 25.25 & 5.83 \\
\hline cis C18:2n6 & 17.32 & 47.4 & 48.19 \\
\hline a C18:3n3 & 0.83 & 7.49 & 21.59 \\
\hline C20:2n6 & 0.48 & 0.27 & 0.81 \\
\hline C20:3n6 & 0.53 & 0.16 & 0.33 \\
\hline C20:4n6 & 0.66 & 0.42 & 0.3 \\
\hline Alti acizi grasi & 0.63 & - & 0.39 \\
\hline S SFAs & 32.89 & 17.41 & - \\
\hline E MUFAs & 46.66 & 26.86 & 24.65 \\
\hline E PUFAs & 19.82 & 55.74 & 51.95 \\
\hline PUFAs/SFAs & 0.603 & 3.20 & 23.42 \\
\hline
\end{tabular}

${ }^{*}$ The values shown in the table represent the average of 3 determinations with RSD $<5 \%$

Table 4: Fatty acids compozition, \% fatty acids, salami samples. 


\begin{tabular}{|c|c|}
\hline Vitamin E ( $\alpha$-tocoferol) & (mg/100g fat) $^{\boldsymbol{*}}$ \\
\hline sea buckthorn oil & $61.736 \pm 8.07$ \\
\hline walnut oil & $5.182 \pm 0.60$ \\
\hline
\end{tabular}

*The values are mean of 3 measures \pm SD

Table 5: Content in vitamin $\mathrm{E}$ in oils.

\begin{tabular}{|l|l|l|l|}
\hline \multirow{2}{*}{ Sample with } & \multicolumn{2}{|l|}{ Vitamin E $(\mathbf{m g} / \mathbf{1 0 0 g}$ fat) } \\
\cline { 2 - 4 } & $\mathbf{4}$ days & $\mathbf{1 1}$ days & $\mathbf{1 8}$ days \\
\hline Sample with back fat & $0.171 \pm 0.003$ & $0.1707 \pm 0.002$ & $0.1395 \pm 0.003$ \\
\hline Sample with walnut oil & $0.5566 \pm 0.009$ & $0.3229 \pm 0.007$ & $0.3793 \pm 0.005$ \\
\hline Sample with sea buckthorn oil & $1.474 \pm 0.014$ & $1.1329 \pm 0.020$ & $1.0855 \pm 0.015$ \\
\hline *The values are mean of 3 measures \pm SD & & \\
\hline
\end{tabular}

Table 6: Vitamin E content salami samples during storage.

\begin{tabular}{|l|c|c|}
\hline Ingredients & PV $(\mathbf{m e q} / \mathbf{k g})^{\star}$ & AC $(\boldsymbol{\mu m o l T E} / \mathbf{g})^{\star *}$ \\
\hline back fat & 7.76 & - \\
\hline walnut oil & 4.53 & $1.38 \pm 0.34$ \\
\hline sea buckthorn oil & 3.3 & $2.015 \pm 0.28$ \\
\hline
\end{tabular}

*The values shown in the table represent the average of three determinations with RSD $<5 \%$

**The values are mean of 2 measures \pm SD

Table 7: Antioxidant capacity of raw materials.

\begin{tabular}{|l|l|l|l|}
\hline Sample with & \multicolumn{3}{|l|}{$\mathbf{P V}(\mathbf{m e q} / \mathbf{k g})^{*}$} \\
\cline { 2 - 4 } & $\mathbf{4}$ days & $\mathbf{1 1}$ days & $\mathbf{1 8}$ days \\
\hline back fat & 17.19 & 13.52 & 11.28 \\
\hline walnut oil & 20.70 & 14.66 & 11.32 \\
\hline sea buckthorn oil & 18.78 & 14.20 & 13.28 \\
\hline
\end{tabular}

*The values shown in the table represent the average of 3 determinations with RSD $<5 \%$

Table 8: Peroxide value salami samples.

\begin{tabular}{|l|l|l|l|}
\hline Sample with & \multicolumn{3}{|l|}{ AC $(\boldsymbol{\mu m o l ~ T E} / \mathbf{g} \text { fat })^{*}$} \\
\cline { 2 - 4 } & $\mathbf{4}$ days & $\mathbf{1 1}$ days & $\mathbf{1 8}$ days \\
\hline back fat & $3.456 \pm 0.05$ & $2.1777 \pm 0.02$ & $1.5220 \pm 2.39$ \\
\hline walnut oil & $4.2101 \pm 0.02$ & $2.7789 \pm 0.18$ & $1.6343 \pm 2.22$ \\
\hline sea buckthorn oil & $4.742 \pm 0.02$ & $3.7908 \pm 0.09$ & $1.9136 \pm 2.33$ \\
\hline
\end{tabular}

*The values are mean of 2 measures \pm SD

Table 9: Antioxidant capacity salami samples.

a) Saturated fatty acids

b) Monounsaturated fatty acids

c) Polyunsaturated fatty acids

\section{Content in vitamin $\mathrm{E}$}

Content in vitamin $\mathrm{E}$ in raw materials is shown in Table 5.

Vitamin E content in samples salami is shown in Table 6.

\section{Antioxidant capacity assessment}

Assessment antioxidant capacity of raw materials is shown in Table 7.

Evolution antioxidant capacity salami samples during storage is shown in Tables 8 and 9.

\section{Discussion}

FAO experts generally classify fatty acids, based on chemical composition (specifying that each fatty acid category has its own chemical properties and distinct biological activity). According to the FAO experts, SFAs refers to saturated fatty acids with the highest intake in the human diet (C14; $\mathrm{C} 16$; $\mathrm{C} 18)$; MUFAs refers to the most important monounsaturated fatty acid existent in the western diets (C18:1n9); PUFAs refers to, mainly, to linoleic acids, to a smaller percentage of $\alpha$-linolenic acid (C18:3n3) and a variable amount of long chain PUFAs (EPA, DHA) [1].

The current study we've tested the addition of vegetal oils to a thermally processed salami batter and we've assessed the influence in regard to lipid oxidation, and the fatty acid content of lipids. It was found that using one type of oil to the salami formulation led to different fatty acid content, according to the lipid profile of the oil used. The vegetal oils with a high content of fat soluble vitamins, aside their important nutritive qualities; also have an antioxidant and colorant role in the food systems. By comparing the fatty acid quantity/100 $\mathrm{g}$ of fatty acids of the samples we've observed that: SFA's has the highest value in the fat sample (32.9\%), PUFA's has the highest value in the sample with walnut oil (55.74\%) and MUFA's has the highest value in the sample with sea-buckthorn sample (51.95\%). A PUFA's/SAFA's ratio close to optimum (optimum=1.1 [1]) was achieved in the case of the sample that had sea-buckthorn oil, 0.957 (Table 4). The intake of a salami portion (100 g) ensures $33-38 \%$ of the daily necessary lipid intake for adults (35 $\mathrm{g}$ fat [1]). The sample with walnut oil has the highest values for essential fatty acids (LA $47.08 \%$ + ALA $22.3 \%=69.38 \%$ ), while the sample with sea-buckthorn oil has a smaller values (LA 23.01\% + ALA $2.57 \%=25.58 \%)($ Table 10$)$.

The addition of high PUFA content vegetal oils, to thermally prepared meat products raises the issue of protection against lipid oxidation. The primary oxidation compounds of lipids (hydroperoxidases and peroxide free radicals, are highly reactive and unstable) reach a synthesis maximum, and a tipping point followed by a decrease due to the synthesis of the secondary oxidation compounds, when the oxidation reaction kinetics reaches equilibrium $[17,18]$. Generally, vitamin E added to food systems target the neutral oil fraction (triacylglycerols) and to a lesser extent the polar lipid fraction (phospholipids) because it is not an effective antioxidant. The Oxygen Reactive Species (ROS), effectively neutralized by the carotenoids, are $\mathrm{O}_{2}^{-}$and peroxyl radicals $\left(\mathrm{RO}_{2}^{*}\right)$. The quenching mechanisms of the oxidative processes are physical: by deactivating the $\mathrm{O}_{2}^{-}$through

\begin{tabular}{|l|c|c|c|}
\hline \multirow{2}{*}{$\begin{array}{l}\text { Fatty acids } \\
\text { (g/100 g fresh sample) }\end{array}$} & \multicolumn{3}{|c|}{ Samples with $^{*}$} \\
\hline C14:0 & Back fat & Walnut oil & Sea buckthorn oil \\
\hline C15:1 & 0.162 & 0.050 & 0.096 \\
\hline C16:0 & 0.021 & 0.015 & 0.017 \\
\hline C16:1 & 2.135 & 1.105 & 1.691 \\
\hline C17:0 & 0.351 & 0.115 & 0.325 \\
\hline C17:1 & 0.031 & 0.012 & 0.018 \\
\hline C18:0 & 0.031 & 0.014 & 0.018 \\
\hline cis C18:1n9 & 0.874 & 0.390 & 0.559 \\
\hline cis C18:2n6 & 4.054 & 2.257 & 4.623 \\
\hline$\alpha$ C18:3n3 & 1.654 & 4.237 & 2.071 \\
\hline C20:2n6 & 0.079 & 0.669 & 0.077 \\
\hline C20:3n6 & 0.046 & 0.024 & 0.032 \\
\hline C20:4n6 & 0.051 & 0.014 & 0.029 \\
\hline$\sum$ SFAs & 0.063 & 0.037 & 0.038 \\
\hline L MUFAs & 3.202 & 1.557 & 2.346 \\
\hline$\sum$ PUFAs & 4.457 & 2.401 & 4.983 \\
\hline PUFAs/ SFAs & 1.893 & 4.981 & 2.246 \\
\hline
\end{tabular}

${ }^{*}$ The values shown in the table represent the average of 3 determinations with $\mathrm{RSD}<5 \%$

Table 10: Fatty acids compozition, \%, fresh sample. 
Citation: Mihociu TE, Israel FR, Belc N, Botez E (2015) The Assessment of Micronutrients Loss in Pasteurized Meat Products with Added Vegetable Oils. J Food Process Technol 6: 411. doi:10.4172/2157-7110.1000411

energy transfer to carotenoids, resulting in a excited carotenoid triplet, and chemical: scavengers of radicals $\mathrm{RO}_{2}{ }^{*}$ through chemical interactions, when the reaction interruption is less than $0.05 \%$ of the antioxidant activity of the carotenoids. Carotenoids are the most effective natural antioxidants for $\mathrm{O}_{2}{ }^{-}$with quenching rate constants of the chain reactions of $5-12 \times 10^{9} / \mathrm{mol}$ per second [19]. The vitamin E content, measured as a-tocopherol is higher in sea-buckthorn 61.7385 $\mathrm{mg} / 100 \mathrm{~g}$ fat, compared to walnut oil, $5.182 \mathrm{mg} / 100 \mathrm{~g}$ fat (Table 5). For antioxidant capacity assessment of the oil vitamins we've measured the composition changes of the lipid fatty acids, the vitamin E content, PV and $\mathrm{AC}$ evolution, during storage.

The evolution of the salami chemical characteristics has underlined the dynamics of the oxidative processes. Thus, the sample with fat (control) has a change in the fatty acid content as follows: SFA's values rise with less than $1 \%$ in regard to initial value, palmitic acid by $0.6 \%$, stearic acid by $0.09 \%$ (Figures 1 and 2), MUFA's values rise by $0.57 \%$, maybe due to measurement deviation (Figure 3), while PUFA's decrease

\section{C16:0 content, $\mathrm{g} / 100 \mathrm{~g}$ fatty acids, during storage}

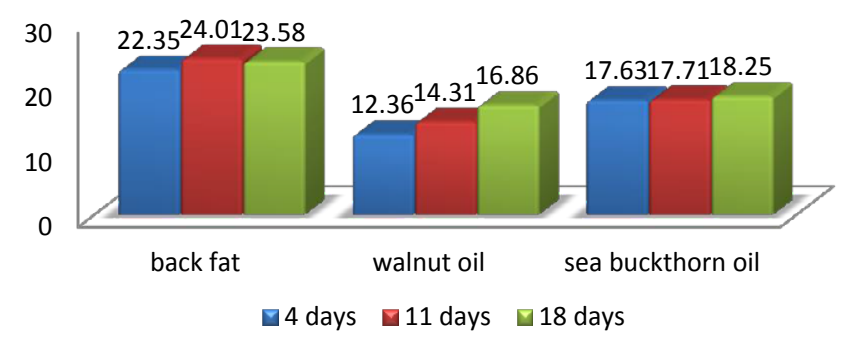

Figure 1: The evolution of the palmitic acid content (C16:0) of salami samples with walnut oil and seabuckthorn oil compared to the control fat.

\section{18:0 content, $\mathrm{g} / 100 \mathrm{~g}$ fatty acids, during storage}

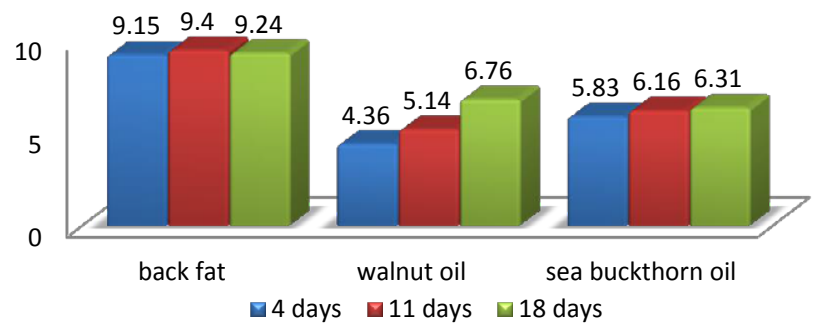

Figure 2: The evolution of the stearic acid content (C18:0) of salami samples with walnut oil and seabuckthorn oil compared to the control fat.

\section{18:1n9 content, $\mathrm{g} / 100 \mathrm{~g}$ fatty acids, during storage}

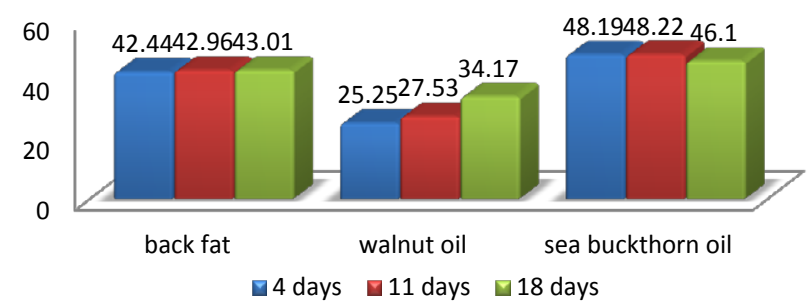

Figure 3: The evolution of the cis oleic acid content $(\mathrm{C} 18: 1 \mathrm{n} 9)$ of salami samples with walnut oil and seabuckthorn oil compared to the control fat.
C 18:2n6 content, g/100 g fatty acids, during storage

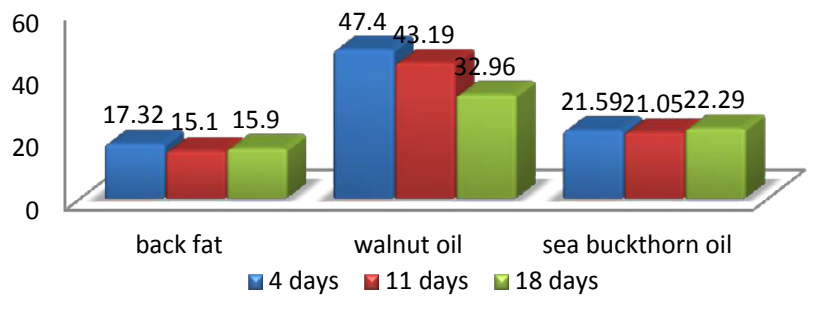

Figure 4: The evolution of the cis linoleic acid content $(C 18: 2 n 6)$ of salam samples with walnut oil and seabuckthorn oil compared to the control fat.

C 18:3n3 content, $\mathrm{g} / 100 \mathrm{~g}$ fatty acids, during storage

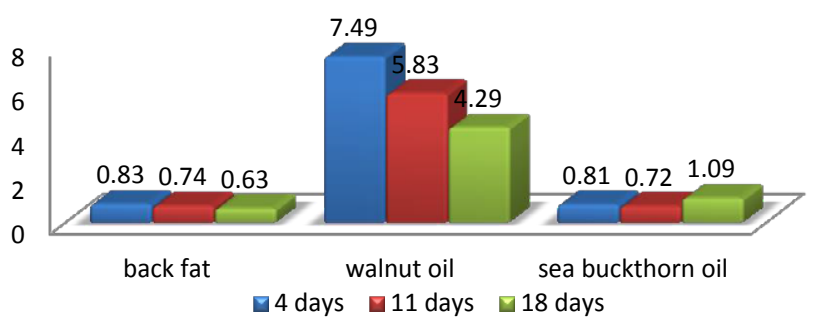

Figure 5: The evolution of the a linolenic acid content $(\mathrm{C} 18: 3 \mathrm{n} 3)$ of salami samples with walnut oil and seabuckthorn oil compared to the control fat.

\section{PUFAs / SFAs, during storage}

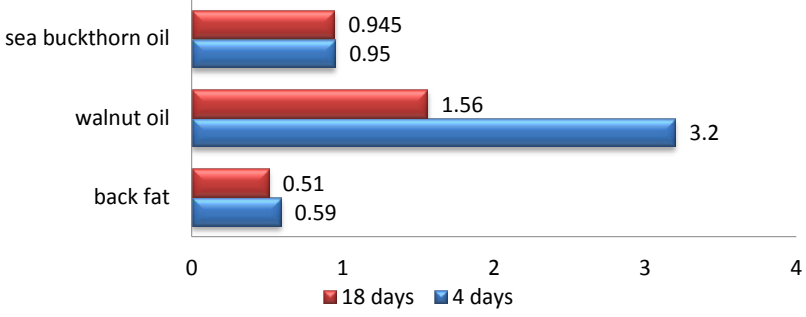

Figure 6: The evolution PUFAs/SFAs, the entire period of storage.

by $1.42 \%$ linoleic acid (Figure 4 ) and $0.2 \%$ linolenic acid (Figure 5). PV registers a constant decrease during storage by $5.9 \mathrm{meq} / \mathrm{kg}$ (Table 8 ) while AC decreases by $56 \%$ from baseline, to a greater extent in the first 11 days of storage $(1.93 \mu \mathrm{mol} \mathrm{TE} / \mathrm{g}$ fat, double in regard to the second storage period) (Table 9). The low tocopherol content $(0.171 \mathrm{mg} / 100 \mathrm{~g}$ fat) decreases by $0.03 \mathrm{mg}$ (Table 6).

We've observed the dynamics of the lipid oxidation reactions in the first 11 days of storage.

The sample with walnut oil, that has a greater PUFA amount, the lipid profile changed as follows: the SAFA content is rising constantly during the storage period, palmitic acid by $26.69 \%$ (Figure 1), stearic acid by $35.5 \%$ (Figure 2). MUFA's, oleic acid values have risen during the second storage period by $26.1 \%$ in regard to baseline (Figure 3 ). As far as PUFA's are concearned linoleic acid drops by $30.46 \%$ (Figure 4 ) to a greater extent in the second storage period and linolenic acid has lower values by $42.72 \%$ (Figure 5 ). The $\alpha$-tocoferol content decreases to a greater extent during the first storage period $0.23 \mathrm{mg} / 100 \mathrm{~g}$ fatty 
$\mathrm{AC}(\mu \mathrm{mol} \mathrm{TE} / \mathrm{g}$ fat$)$ during storage

$\square$ days $\square 11$ days $\square 18$ days

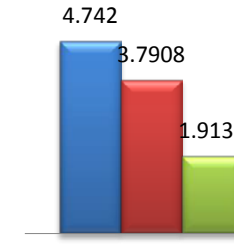

sea buckthorn oil

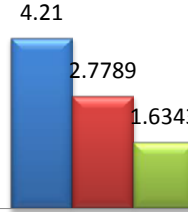

walnut oil
3.456

back fat

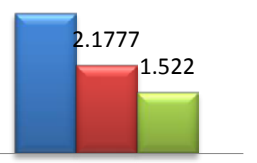

Figure 7: Evolution antioxidant capacity salami samples during storage.

acids, registering a slight increase during the second stage $0.056 \mathrm{mg} / 100$ $\mathrm{g}$ fatty acids (Tables 6 and 7). PV has the highest values compared to the other samples and a constant decrease during storage $9.38 \mathrm{meq} /$ $\mathrm{kg}$ (Tables 8 and 9). AC decreases by $2.57 \mu \mathrm{mol}$ TE/g fat $(61.18 \%)$ constantly during storage (Figure 6).

It has been found the highest intensity of the oxidation reaction compared to the other samples, a constant evolution during whole storage period.

The sea-buckthorn sample has the highest content of MUFA fatty acids (Table 10). The chemical composition changes during storage were as follows: the lipid profile of the SFA fatty acids rise with $<1 \%$, the palmitic acid values increase by $0.62 \%$ (Figure 1 ) and the stearic acid by $0.48 \%$ (Figure 2 ) maybe due to measurement deviation; MUFA fatty acids (Figure 3 ) (oleic acid) records a decrease by $2 \%$ in the final storage stage; PUFA fatty acids decrease by $<1 \%$, linoleic acid by $0.7 \%$ (Figure 4), linolenic acid by $0.28 \%$ (Figure 5 ) maybe due to measurement deviation; the $a$-tocopherol consumption is $0.43 \mathrm{mg} / 100 \mathrm{~g}$ fatty acids during the first 11 days of storage, and in the following 7 days has a value of $0.047 \mathrm{mg}$ (aprox. 10 times smaller) (Table 6), while PV decreases by $4.58 \mathrm{meq} / \mathrm{kg}$ during the first 11 days and by $0.92 \mathrm{meq} / \mathrm{kg}$ during the final storage stage (Table 8). Total AC decreases by double in the second storage stage than in the first 11 days of storage, with a decrease of $2.828 \mu \mathrm{mol} \mathrm{TE} / \mathrm{g}$ fat (Table 9).

Lipid oxidation reactions rise in intensity after 11 days of storage, the sample with sea-buckthorn oil was the most stable during storage.

The PUFAs/SFAs (Figure 7) ratio highlights the changes in fatty acids $/ 100 \mathrm{~g}$ fatty acids content during storage, where one can notice the dynamics of lipid oxidation depending on the salami's composition of fatty acids, the content of fat-soluble vitamins of the oils.

\section{Conclusion}

Partial or total back fat replacement with vegetable oils in meat products by a percentage relevant for changing the fatty acid content of lipids to an increase in the nutritional value by improving the PUFAs/ SFAs ratio and the content of essential fatty acids.

The addition of oil with high content of PUFAs consisting of more than two double bonds in the matrix of the salami using thermal treatment generates intense lipid oxidation reactions in the absence of sufficient protection obtained through the addition of antioxidants, since the addition of $10 \mathrm{mg} / \mathrm{kg}$ of $\mathrm{NaNO}_{2}$ is not effective.

The losses of essential fatty acids are highly significant, those in salami samples with thermal treatment exceeding $40 \%$ in a linolenic acid, $30 \%$ in cis linoleic acid, and $26 \%$ in cis oleic acid, especially when adding $4 \%$ of vegetable oils containing $>70 \%$ of PUFAs fatty acids.
The oils rich in fat-soluble vitamins (tocopherols and carotenoids such as seabuckthorn oil) containing $>50 \%$ MUFAs added into a salami paste using thermal treatment ensure an average stability for lipid oxidation ( 10 days of refrigeration) and a low loss of essential fatty acids.

A recent technological model uses the microencapsulation of valuable nutritional oils for food reformulation. Although this technology solves the problem of lipid oxidation, it is not yet widely used due to very high costs.

\section{Acknowledgment}

Studies were performed in the national research program, project no. PN-II-PTPCCA-2011-3.2-0609, contract no. 115/01.07.2012, MEN funded by UEFISCDI, Romania. The authors would like to thank the SC RECUNOSTINTA PRODCOM IMPEX SRL, Prahova county, Romania, for co-financing activities.

\section{Author Contributions}

${ }^{1} \mathrm{NRDIFB}-I B A$ a coordonat studiul, a realizat probele de salam si a efectuat determinari chimice si $A C$;

${ }^{2} \mathrm{UASMV} / \mathrm{CBAB}$ a efectuat determinari ale acizilor grasi si Vitamina $\mathrm{E}$;

${ }^{3} \mathrm{FSEFU}$ a efectuat un studiu de caracterizare a uleiurilor vegetale.

\section{References}

1. FAO Fats and fatty acids in human nutrition (2010) Food and Nutrition.

2. Fat and fatty acid requirements for adult, FAO, Fats and fatty acids in human nutrition (2010) Food and Nutrition.

3. Arihara K (2006) Strategies for designing novel functional meat products. Meat Science 74: 219-229.

4. Hadorn R, Eberhard P, Guggisberg D, Piccinali P, Schlichtherle-Cerny $H$ (2008) Effect of fat score on the quality of various meat products. Meat Sci 80: $765-770$.

5. Dunshea FR, D'Souza DN, Pethick DW, Harper GS, Warner RD (2005) Effects of dietary factors and other metabolic modifiers on quality and nutritional value of meat. Meat Sci 71: 8-38.

6. Paiva-Martins F, Barbosa S, Pinheiro V, Mourao JL, Outor-Monteiro D (2009) The effect of olive leaves supplementation on the feed digestibility, growth performances of pigs and quality of pork meat. Meat Science 82: 438-443.

7. López-López I, Cofrades S, Ruiz-Capillas C, Jiménez-Colmenero F (2009) Design and nutritional properties of potential functional frankfurters based on lipid formulation, added seaweed and low salt content Meat Sci 83: 255-262.

8. Zhang W, Xiao S, Samaraweera H, Lee EJ, Ahn DU (2010) Improving functional value of meat products. Meat Sci 86: 15-31.

9. Jimenez-Colmenero F, Reig M, Toldra F (2006) New Approaches for the Development of Functional Meat Products. Advanced technologies for meat processing, CRC Press, Taylor \& Francis Group, Publisher in New York, USA.

10. Jimenez-Colmenero $F(2007)$ Healthier lipid formulation approaches in meat based functional foods. Technological options for replacement of meat fats by non-meat fats. Trends in Food Science \& Technology 18: 567-578.

11. Scalbert A, Johnson IT, Saltmarsh M (2005) Polyphenols: antioxidants and beyond. Am J Clin Nutr 81: 215S-217S.

12. Brewer MS (2011) Natural Antioxidants: Sources, Compounds, Mechanisms of Action, and Potential Applications. Institute of Food Technologists, Comprehensive Reviews in Food Science and Food Safety 10: 221-247.

13. Arranz S, Pérez-Jiménez J, Saura-Calixto F (2008) Antioxidant capacity of walnut (Juglans regia L.) contribution of oil and defatted matter. Eur Food Res Technol 227: 425-431.

14. Pereira JA, Oliveira I, Sousa A Ferreira IC, Bento A Estevinho L (2008) Bioactive properties and chemical composition of six walnut (Juglans regia L.) cultivars. Food Chem Toxicol 46: 2103-2111.

15. Dulf FV (2012) Fatty acids in berry lipids of six sea buckthorn (Hippophae rhamnoides L., subspecies carpatica) cultivars grown in Romania. Chem Cent J 6: 106.

16. Arimboor R, Kumar KS, Arumughan C (2008) Simultaneous estimation of 
Citation: Mihociu TE, Israel FR, Belc N, Botez E (2015) The Assessment of Micronutrients Loss in Pasteurized Meat Products with Added Vegetable Oils. J Food Process Technol 6: 411. doi:10.4172/2157-7110.1000411

Page 7 of 7

phenolic acids in sea buckthorn (Hippophaë rhamnoides) using RP-HPLC with DAD. J Pharm Biomed Anal 47: 31-38

17. Erkkola R, Yang B (2003) Sea buckthorn oils: Towardshealthy mucous membrane, AGROFood industry hi-tech, Women's Health.

18. Giua L, Blasi F, Simonetti MS, Cossignani L (2013) Oxidative modifications of conjugated and unconjugated linoleic acid during heating. Food Chem 140: 680-685.

19. Decker E, Elias R, McClements DJ (2010) Oxidation in foods and beverages and antioxidant applications. In: Understanding mechanisms of oxidation and antioxidant activity, in Food Science, Technology and Nutrition, Woodhead Publishing Series.
20. Wood JD, Enser M (1997) Factors influencing fatty acids in meat and the role of antioxidants in improving meat quality. Br J Nutr 78 Suppl 1: S49-60.

21. Parunović N, Petrović M, Matekalo-Sverak V, Trbović D, Mijatović M, et al (2012) Fatty acid profile and cholesterol content of $\mathrm{m}$. longissimus of free-range and conventionally reared Mangalitsa pigs. South African Journal of Animal Science 42: 101-113.

22. Fatima T, Snyder CL, Schroeder WR, Cram D, Datla R, et al. (2012) Fatty Acid Composition of Developing Sea Buckthorn (Hippophae rhamnoides L.) Berry and the Transcriptome of the Mature Seed. PLoS ONE 7: e34099. 